\title{
Article \\ A Medium-Term Field Experiment to Study the Effect of Managing Soil Chemical Properties on Fusarium Wilt in Banana (Musa AAA)
}

\author{
Rafael A. Segura M. ${ }^{1,2, * \mathbb{D}}$, Jetse J. Stoorvogel ${ }^{1}$, , Fabio A. Blanco R. ${ }^{3}$ and Jorge A. Sandoval F. ${ }^{2}$ \\ 1 Soil Geography and Landscape Group, Wageningen University, 6708 PB Wageningen, The Netherlands; \\ jetse.stoorvogel@wur.nl \\ 2 Research Center, CORBANA S.A., Guápiles 32-7210, Costa Rica; jsandoval@corbana.co.cr \\ 3 Independent Consultant, Barva 40202, Costa Rica; fabioa.blanco@gmail.com \\ * Correspondence: rafael.seguramena@wur.nl or rsegura@corbana.co.cr; Tel.: +506-40024671
}

Citation: Segura M., R.A.;

Stoorvogel, J.J;; Blanco R., F.A.;

Sandoval F., J.A. A Medium-Term Field Experiment to Study the Effect of Managing Soil Chemical Properties on Fusarium Wilt in Banana

(Musa AAA). J. Fungi 2021, 7, 261.

https://doi.org/10.3390/jof7040261

Academic Editor: Guy Blomme

Received: 30 January 2021

Accepted: 26 March 2021

Published: 31 March 2021

Publisher's Note: MDPI stays neutral with regard to jurisdictional claims in published maps and institutional affiliations.

Copyright: () 2021 by the authors. Licensee MDPI, Basel, Switzerland. This article is an open access article distributed under the terms and conditions of the Creative Commons Attribution (CC BY) license (https:// creativecommons.org/licenses/by/ $4.0 /)$.

\begin{abstract}
Fusarium oxysporum f. sp. cubense (Foc) is a soil-borne fungus causing Fusarium wilt (FW) in banana. It is practically impossible to eradicate Foc in soils. Our understanding of soilFoc-banana interactions is hampered by inconsistent research results caused by agro-ecological variability and the complexity of the soil system. This study aimed to evaluate the options to manage soil chemical properties to reduce disease expression and maintain banana production. The expression of FW (Foc Race 1) and the agronomic performance of the Gros Michel (Musa AAA) banana were evaluated in two medium-term factorial field experiments at representative locations in the Costa Rican banana region. In the experiments, five soil chemical properties $(\mathrm{pH}, \mathrm{N}, \mathrm{Ca}$, $\mathrm{Mg}$, and $\mathrm{Mn}$ ) were managed to achieve a low and a high level. Plant mortality caused by FW, soil fertility, plant nutrition, and agronomic performance were monitored during four crop cycles. After the first crop cycle, the treatments started to present differences in plant mortality. There was a significant rise of plant mortality after the second crop cycle resulting in a cumulative plant mortality exceeding $60 \%$ in both experiments. A lower soil $\mathrm{pH}$ consistently resulted in significantly higher plant mortality. The interactions between soil properties ( $\mathrm{pH}-\mathrm{N}, \mathrm{pH}-\mathrm{CaMg}, \mathrm{pH}-\mathrm{Mn}, \mathrm{N}-\mathrm{Mn}$, and CaMg-Mn) also influenced plant mortality. Soil $\mathrm{N}$ was the most significant treatment affecting leaf nutrient concentrations, bunch weight, and clusters per bunch. The experiments confirmed the potential role of soil management in FW expression in banana. Our results suggest that the management of soil chemical properties in the conditions here studied may help to reduce the expression rate of FW, but not to control the disease in the long run.
\end{abstract}

Keywords: Costa Rica; Panama disease; plant nutrition; soil fertility; soil type

\section{Introduction}

Global crop production is seriously hampered by crop diseases [1-3]. Fusarium wilt (FW) in banana is a prime example. FW (also known as Panama disease) is caused by the soil-borne fungus Fusarium oxysporum f. sp. cubense (Foc). Global banana production has been threatened by four Foc races: Race 1, Race 2, Subtropical Race 4, and Tropical Race 4 (TR4) [4,5]. Foc Race 1 decimated the commercial production of the Gros Michel banana (a sub-group of Musa AAA), which used to be the main cultivar in Latin America and the Caribbean (LAC) until a major outbreak of FW in the first half of the 20th century [6]. The social and economic impacts in the region were substantial [7]. After struggling with the disease, Cavendish (another sub-group of Musa AAA) was found to be naturally resistant to Foc Race 1. The most effective option to maintain banana exports was to replace the Gros Michel banana by Cavendish bananas [4,8-10]. Despite the availability of the resistant Cavendish, Gros Michel is still being produced in LAC in smallholder systems, as its specific traits are preferred for local trade and consumption [11]. Bananas (Musa AAA) 
that are susceptible to Race 1 (including Gros Michel) and also plantains (Musa ABB) remain important sources of incomes and represent around 30\% of the global banana production [12,13]. At the end of the 20th century TR4 appeared in Asia and started to spread affecting most banana cultivars including the important Cavendish cultivar.

Efficient practices to eradicate or control Foc in infested soils are lacking. Foc is a highly competitive fungus and it can survive in the soil for decades [14]. Soil flooding was widely implemented to eradicate the soil-borne fungus during the outbreak of Race 1. Rather than eradicating Foc, this practice contributed to the further dissemination of Race $1[4,15,16]$. Other control practices, such as the application of fungicides, replanting, and the eradication of infested plants, were tested but with mostly negative results. In most cases, the aggressive character of the disease did not allow for further commercial banana production $[4,17]$.

Despite a general awareness of the potential of soil management in the control of this disease [4,17-22], it is still not considered as a viable strategy to control FW in banana. The experimental results in the literature are inconsistent making it difficult to identify recommendations for soil management to control or alleviate the effect of the disease. In general, soil properties are known to influence the predisposition of crops to diseases [23-25]. Therefore, it is likely that crop predisposition to diseases can be influenced by soil management [26,27]. However, given the large number of soil properties, it is important to identify which soil properties influence the predisposition of a crop to diseases. Soil properties that can be changed easily through management (e.g., fertilization, liming, tillage, and drainage) can be considered as first candidates for crop disease management.

Although many soil properties and their interactions are involved in crop development and production, some soil properties are commonly referred to in the scientific literature as important drivers for disease development in crops. Nonetheless, the scientific community still lacks a proper understanding of the role of soil properties on crop disease development. In this study, we focus on soil chemical properties that can be influenced by soil management. Soil $\mathrm{pH}$ and nitrogen $(\mathrm{N})$, for instance, are two important soil properties in crop production. Moreover, they are frequently mentioned to influence the crop response to diseases [28-31]. Other soil properties as calcium (Ca) [25,32,33], magnesium (Mg) [34], and manganese (Mn) [35] are reported to influence crop diseases [36].

The relation between soil properties and FW is mostly studied in greenhouse experiments. The advantage of the greenhouse experimentation is the possibility to vary one or a limited number of properties under controlled conditions to derive a specific relationship. The disadvantages of the greenhouse experiments with large perennial crops like banana is that it is very difficult to carry out the experiment for an entire crop cycle, let alone over multiple crop cycles. Many greenhouse experiments with banana are carried for a relatively short period of 8-15 weeks on small plants [37]. Therefore, it is very important to confirm the results from greenhouse experiments under field conditions [37]. Alternatively, farm surveys are carried out where FW is observed on farms and correlated to soil analyses from those locations [20,21]. Agro-ecological conditions can be extremely variable and require many observations to carry out multivariate analysis to unravel the complex relationships [38]. Performing field experiments in representative banana producing areas, over multiple crop cycles can provide useful information about the Foc-soil-banana interactions. Field experiments looking at the banana response to the Foc infestation over various crop cycles under natural ecological conditions can show the true potential of soil management on the disease expression and how it affects crop production.

Given the impact of FW on banana production and the ineffectiveness of current management strategies to control or eradicate the fungus from infested soils, there is an urgent need for new approaches. Genetic resistance is considered an effective solution against FW and has proven itself in the past $[39,40]$. However, it requires time to develop resistant varieties that are accepted by the producer and consumer. Integral solutions to face current problems caused by FW in the diverse banana scenarios are required. This paper hypothesizes on the basis of experimental proof from greenhouse experiments that soil chemical properties influence the predisposition of banana to Foc Race 1. This study aims to evaluate whether 
the crop behaves similarly under field conditions in Costa Rica and over multiple crop cycles in order to develop strategies to maintain the production even in Foc infestation conditions. Experiments with Gros Michel banana and Foc Race 1 may also help in preparing for the eventual arrival of Foc TR4 and the Cavendish production. The role of soil properties on Foc Race 1 was found to be similar to the role of soil properties on Foc TR4 [41]. The latter is especially relevant with the recent arrival of Foc TR4 in LAC [42,43].

\section{Materials and Methods}

\subsection{Study Area}

The main banana region of Costa Rica is located in the Caribbean lowlands in the North East of the country [44]. The region exhibits diverse soil conditions and is typically divided into two sub-regions defined by the location with respect to the Reventazón river. Soils east of the Reventazón river are predominantly sedimentary, fertile, (loamy) clay soils. Soils at the western side originate from sedimentary materials and volcanic ashes with (sandy) loam textures and an intermediate soil fertility [45-47]. More than $95 \%$ of the Costa Rican banana production takes place on those soil types [44].

Experimental sites were established on two locations within the representative soils used for banana production. Both experiments are located on research stations of the Costa Rican Corporation of Banana Producers (CORBANA S.A.). The experiment in the western region (Exp-west) was located at the La Rita experimental station (132 m.a.s.l.; $10^{\circ} 15^{\prime} 54^{\prime \prime} \mathrm{N}$, $\left.83^{\circ} 46^{\prime} 26^{\prime \prime} \mathrm{W}\right)$. The experiment in the eastern region (Exp-east) was located in 28 Millas (4 m.a.s.l.; $10^{\circ} 06^{\prime} 40^{\prime \prime} \mathrm{N}, 83^{\circ} 22^{\prime} 53^{\prime \prime} \mathrm{W}$ ). Both locations have a perhumid tropical climate with an average annual rainfall of 3000-3500 $\mathrm{mm}$ well distributed throughout the year and with minimum temperatures around $17^{\circ} \mathrm{C}$ and maximum temperatures around $35^{\circ} \mathrm{C}$.

\subsection{Experimental Setup}

Exp-west covered 0.5 ha in an area that was used for banana production but fallow two years prior to the experiment. Exp-east covered 0.8 ha in an area that was used for plantain production, but that also had been fallow two years prior to the experiment. The experiments took place between November 2014 and July 2018. The fallow vegetation was cleared manually, and the residues left on the soil as mulch. Both areas had an intensive drainage infrastructure typical for Costa Rican banana plantations. The drainage channels were cleaned before the start of the experiment. The experiments were designed as a factorial trial studying the effect of four different soil properties: $\mathrm{pH}$, Nitrogen (N), Calcium + Magnesium (CaMg), and Manganese (Mn). Ca and $\mathrm{Mg}$ are found to be highly correlated in Costa Rican banana soils [48] and are therefore included in a combined treatment in the experimental setup. Each of the soil properties were studied at two levels and the overall experiment had four replications. The area was sub-divided into 64 plots (16 treatments with 4 replications) as displayed in Figure 1. Planting was done with tissue culture Gros Michel banana plants, following standard commercial practices. In both experiments planting was done in a triangular planting pattern at a density of approx. 1600 plants per ha corresponding to an average commercial plant density. Each plot in Exp-west included 7-8 plants (486 plants in the entire experiment), whereas plots in the larger Exp-east included 15-18 plants (1160 plants in the entire experiment). The experiment was maintained for four crop cycles. 


\begin{tabular}{|l|l|l|l|}
\hline 1:0:0:0 & $1: 0: 1: 1$ & $0: 0: 0: 0$ & $0: 0: 1: 1$ \\
\hline 1:1:0:1 & $1: 1: 1: 0$ & $0: 1: 0: 1$ & $0: 1: 1: 0$ \\
\hline $0: 0: 1: 0$ & $0: 1: 1: 1$ & $1: 1: 0: 0$ & $1: 0: 0: 1$ \\
\hline $0: 1: 0: 0$ & $0: 0: 0: 1$ & $1: 0: 1: 0$ & $1: 1: 1: 1$ \\
\hline
\end{tabular}

\begin{tabular}{|l|l|l|l|}
\hline 1:1:0:1 & 1:0:1:1 & $0: 1: 0: 1$ & $0: 1: 1: 0$ \\
\hline 1:1:1:0 & 1:0:0:0 & $0: 0: 0: 0$ & $0: 0: 1: 1$ \\
\hline $0: 0: 0: 1$ & $0: 1: 0: 0$ & 1:0:0:1 & 1:1:0:0 \\
\hline 0:1:1:1 & $0: 0: 1: 0$ & 1:0:1:0 & 1:1:1:1 \\
\hline
\end{tabular}

\begin{tabular}{|l|l|l|l|}
\hline 1:1:0:0 & 1:0:1:0 & 0:1:0:0 & 0:0:1:0 \\
\hline 1:0:0:1 & 1:1:1:1 & $0: 0: 0: 1$ & $0: 1: 1: 1$ \\
\hline 0:1:0:1 & $0: 0: 1: 1$ & 1:0:0:0 & 1:0:1:1 \\
\hline 0:0:0:0 & $0: 1: 1: 0$ & 1:1:1:0 & 1:1:0:1 \\
\hline
\end{tabular}

\begin{tabular}{|l|l|l|l|}
\hline 1:1:0:0 & $1: 1: 1: 1$ & $0: 0: 0: 1$ & $0: 1: 0: 0$ \\
\hline 1:0:0:1 & $1: 0: 1: 0$ & $0: 0: 1: 0$ & $0: 1: 1: 1$ \\
\hline $0: 1: 0: 1$ & $0: 1: 1: 0$ & 1:0:0:0 & 1:1:0:1 \\
\hline $0: 0: 0: 0$ & $0: 0: 1: 1$ & 1:1:1:0 & 1:0:1:1 \\
\hline
\end{tabular}

Figure 1. Design of the factorial experiment with 2 levels of four soil properties: $\mathrm{pH}, \mathrm{N}, \mathrm{CaMg}$, and Mn (represented as $\mathrm{pH}: \mathrm{N}: \mathrm{CaMg}: \mathrm{Mn}$ with a 0 for the low level and a 1 for the high level) with 4 replications of each treatment.

\subsection{Plant Inoculation}

Foc Race 1 is regarded as endemic in Costa Rican banana soils although the levels do vary considerably. As a result, a treatment without Foc Race 1 in the experiment would have been difficult to achieve. To ensure a homogeneous (relatively high) infestation throughout the experiments, each plant within the experiments was artificially inoculated twice with $5 \mathrm{~g}$ of rice colonized with Foc Race 1 collected from Costa Rican soils and cultivated by the Laboratory of Biological Control (CORBANA's Research Center). The procedure of rice inoculation is novel and in process of publication, but the density of rice colonization was at least $1 \times 10^{5}$ Foc conidia per $g$ rice. The first artificial inoculation took place seven weeks after planting and a second artificial inoculation took place at the end of the 1st cycle, around 50 weeks after planting. The rice (with Foc Race 1) was buried $15 \mathrm{~cm}$ deep at the base of the plant for the first inoculation, and in front of the following sucker for the second inoculation. A control without inoculation was not included due to the natural soil infestation with Foc Race 1 in both experimental areas.

\subsection{Soil Management}

Soil management is described in Table 1 . The experiments were established in a complete factorial design considering four main soil chemical properties for banana production ( $\mathrm{pH}, \mathrm{N}, \mathrm{CaMg}$ and $\mathrm{Mn}$ ) with two contrasting levels (low and high) each. The experiments started with a uniform management including the application of compost at planting and a basic startup fertilization during the first 7 weeks. This startup fertilization program is standard for new plantations. Differentiation in the fertilization with $\mathrm{N}, \mathrm{CaMg}$, and $\mathrm{Mn}$ started in week 8 . The various treatments are supplemented with a standard nutritional package for all the nutrients that were not part of the treatments. The application of this standard nutritional package also started in week 8. Changes in $\mathrm{pH}$ levels (either through acidification or liming) were made at three distinct moments during the experiment: before planting, at the start of the various treatments, and between cycle 2 and 3 . 
Table 1. Treatments in the factorial experiment to study the effect of managing soil chemical properties on FW in Gros Michel banana in the Costa Rican banana region.

\begin{tabular}{|c|c|c|c|}
\hline \multicolumn{2}{|c|}{ Soil Management } & \multirow[t]{2}{*}{ Application } & \multirow[t]{2}{*}{ Timing } \\
\hline General & & & \\
\hline & Compost & $1 \mathrm{~kg}$ per plant in each planting hole & At planting \\
\hline & Startup fertilization & $\begin{array}{c}100 \mathrm{~N}, 18 \mathrm{~K}_{2} \mathrm{O}, 27 \mathrm{MgO}, 53 \mathrm{CaO}, 20 \mathrm{~S}, 5.8 \\
\mathrm{Zn} \text { and } 0.8 \mathrm{~B}\left(\mathrm{in} \mathrm{kg} \mathrm{ha}{ }^{-1} \text { year }^{-1} \text { ) }\right.\end{array}$ & $\begin{array}{l}\text { During the first } 7 \text { weeks, divided } \\
\text { over weekly applications. }\end{array}$ \\
\hline & Basic nutritional package [36] & $\begin{array}{c}105 \mathrm{P}_{2} \mathrm{O}_{5}, 610 \mathrm{~K}_{2} \mathrm{O}, 4.0 \mathrm{CaO}, 60 \mathrm{~S}, 9.2 \mathrm{Zn} \\
\text { and 3.2 } \mathrm{B}\left(\mathrm{in} \mathrm{kg} \mathrm{ha}^{-1} \text { year }^{-1}\right)\end{array}$ & $\begin{array}{l}\text { After week 8, divided over } 17 \\
\text { 3-weekly applications per year }\end{array}$ \\
\hline \multirow[t]{5}{*}{ Treatments } & & & \\
\hline & $\mathrm{pH}$ & $\begin{array}{c}\text { Low: } \\
300 \mathrm{~mL} \text { of } 5 \% \mathrm{HCl} \text { solution and } 303 \mathrm{~g} \text { of } \\
\mathrm{CaO}^{1} \text { per plant per application } \\
\mathrm{High} \text { : } \\
400 \mathrm{~g} \text { of } \mathrm{Ca}(\mathrm{OH})_{2} \text { per plant per } \\
\text { application }\end{array}$ & $\begin{array}{l}1 \text { week before planting; } \\
8 \text { weeks after planting; } \\
\text { between cycle } 2 \text { and } 3\end{array}$ \\
\hline & $\mathrm{N}$ & $\begin{array}{c}\text { Low: } \\
232 \mathrm{~kg} \mathrm{~N} \mathrm{ha}^{-1} \text { year }^{-1} \text { with } \mathrm{NH}_{4} \mathrm{NO}_{3} \text { and } \\
\mathrm{CaNO}_{3} \\
\text { High: } \\
605 \mathrm{~kg} \mathrm{ha}^{-1} \text { year }{ }^{-1} \text { with } \mathrm{NH}_{4} \mathrm{NO}_{3} \text { and } \\
\mathrm{CaNO}_{3}\end{array}$ & $\begin{array}{l}\text { Starting in week } 8 \text {. Divided over } \\
17 \text {-weekly applications per year }\end{array}$ \\
\hline & $\mathrm{CaMg}^{2}$ & $\begin{array}{c}\text { Low: - } \\
\text { High: } \\
315 \mathrm{~kg} \mathrm{CaO} \mathrm{ha}^{-1} \text { year }^{-1} \text { with } \mathrm{Ca}_{3}\left(\mathrm{BO}_{3}\right)_{2} \\
\text { and } \mathrm{CaNO}_{3 .} 150 \mathrm{~kg} \mathrm{MgO} \mathrm{ha}^{-1} \text { year }^{-1} \\
\text { with } \mathrm{MgSO}_{4}\end{array}$ & $\begin{array}{l}\text { Starting in week } 8 \text {. Divided over } \\
17 \text {-weekly applications per year }\end{array}$ \\
\hline & Mn & $\begin{array}{c}\text { Low: - } \\
\text { High: } \\
32 \mathrm{~kg} \mathrm{Mn} \mathrm{ha}^{-1} \text { year }^{-1} \text { with } \mathrm{MnSO}_{4}\end{array}$ & $\begin{array}{l}\text { Starting in week } 8 \text {. Divided over } \\
17 \text {-weekly applications per year }\end{array}$ \\
\hline
\end{tabular}

${ }^{1} \mathrm{CaO}$ is applied to the low $\mathrm{pH}$ treatment to compensate for the $\mathrm{Ca}$ input in the high $\mathrm{pH}$ treatment. ${ }^{2} \mathrm{Ca}$ is also applied with the $\mathrm{pH}$ treatments and as part of the basic nutritional package as it comes with the borate application.

\subsection{Plant Monitoring}

Plant mortality was recorded as a percentage during the four crop cycles as the main indicator of the Fusarium wilt incidence. Plant mortality by FW was obtained by registering the harvested plants at the end of each crop cycle against the total plants at the beginning of the experimental period. An infested plant (showing symptoms) died in most of the cases. Plants that were not harvested almost exclusively died as a result of FW as indicated by the typical symptoms of wilting and pseudostem splitting. Those plants were not replaced during the experiment. Mortality was therefore a cumulative number over the entire experiment (four crop cycles).

Soil chemical properties were analyzed at the beginning of the experiments [49] (before the application of any treatment), a second analysis took place between the 1st and 2nd cycle (before the third $\mathrm{pH}$ (liming or acidification) treatment) and a third analysis took place between the $3 \mathrm{rd}$ and the 4 th cycle. Soils were sampled at 0-30 $\mathrm{cm}$ depth in front of the following sucker at flowering with a gouge auger.

Leaf samples from the medium section of the third leave of plants were taken for a complete analysis of leaf nutrient concentrations at flowering in the 1st and 2nd crop cycle. The leaf analysis included N, P, K, Ca, Mg, S, Fe, Cu, Zn, Mn and B. Agronomic performance was measured in terms of plant height, pseudostem circumference (at $1 \mathrm{~m}$ above the ground), and clusters or hands per bunch at flowering [44]. The bunch weight was measured at harvest (at the end of each crop cycle) 80 days after flowering (the average of the standard harvesting age in Costa Rican plantations). With the bunch weight, the density per ha and the plant mortality, a projection of the total harvested fruit ha ${ }^{-1}$ crop 
cycle $^{-1}$ was calculated in each experiment. Sampling and data collection were carried out during the 1st and 2nd crop cycle. Due the detrimental effect of the disease on the plants after the 2nd crop cycle, the evaluation of agronomic performance and leaf nutrient analysis were not performed for the 3 rd and the 4th crop cycle.

\subsection{Statistical Analysis}

Data analysis was done separately for each region but following the same protocol. The mean was modeled by a full factorial design of five fixed factors, namely $\mathrm{pH}, \mathrm{N}, \mathrm{CaMg}$, $\mathrm{Mn}$, and crop cycle. The whole data analysis was performed using R statistics [50].

Plant mortality was analyzed using the logit of dead plants $(\operatorname{logit}(\mathrm{p})=\log (\mathrm{p} /(1-\mathrm{p})$, where $\mathrm{p}=$ proportion of dead plants) as response variable. The generalized estimation equation (GEE) technique was used, taking as repeated measures the counts of dead plants by FW across the 2nd, 3rd, and 4th crop cycles. The 1st crop cycle was omitted in the analysis because its plant mortality ranged within the normal limits of healthy plantations (around $2 \%$ ). The binomial variance function was applied to model residues distribution since mortality outcomes are of the binomial type. Also, the first order autoregressive (ar1) correlation structure was chosen to model the repeated measures after being compared to the "independence" and "exchangeable" structures. The geeglm function of the geepack package [51-53]. Apart from the above-described analysis, an ordinary regression analysis of percent of plant mortality on soil $\mathrm{pH}$ values of the whole plots in each experiment was performed.

All the agronomic variables (plant height, pseudostem circumference, clusters or hands per bunch, and bunch weight) and the leaf nutrient concentrations were analyzed using a linear mixed model in which replicates were the only random factor and crop cycle was a repeated measures factor. Heteteroscedasticity across crop cycles and correlated measurements were accounted for through the varFixed correlation structure. The lme function of the nlme package was used for computations. The analyses of soil and leaf nutrient concentration were similar to those of the agronomic variables, except that it was not necessary to include heteroscedasticity in the model. In all the analyses, the means of main factors levels and of combinations of them were obtained and tested using the emmeans package [54].

\section{Results}

\subsection{Plant Mortality}

Plant mortality was relatively low in the 1 st and the 2 nd crop cycle. However, after the second crop cycle plant mortality increased rapidly (Figure 2). In the 1st crop cycle, the average mortality was minimal (around 1\%) in both experiments. The 2nd crop cycle showed an increase in mortality in the experiments, up to $11 \%$ in Exp-west and $20 \%$ in Exp-east. A rapid and significant increase $(p \leq 0.001)$ of plant mortality occurred after the 2nd crop cycle in both experiments (Figure 2).

Plant mortality also differed as a result of the different treatments in the 2nd, 3rd, and 4th crop cycle (Figure 3). pH-low was linked with a higher plant mortality by FW for both experiments in the $3 \mathrm{rd}(p \leq 0.001)$ and the 4 th $(p \leq 0.001)$ crop cycle. In the statistical tests, all plots are included to have a sufficient number of observations, although this may have been a source of variation in the groups. Differences in mortality between $\mathrm{pH}$-low and pH-high varied from $14 \%$ to $17 \%$ in the Exp-west and from $16 \%$ to $22 \%$ in Exp-east. The $\mathrm{N}$ level did not influence the plant mortality in the 3rd $(p=0.873)$ and the 4th $(p=0.162)$ crop cycle in Exp-west. In Exp-east a higher plant mortality was linked with N-high only in the 3rd $(p \leq 0.030)$ crop cycle. The effect was less significant $(p \leq 0.070)$ in the 4th crop cycle, but the same trend was observed. The effect of CaMg $(p \leq 0.025)$ and $\mathrm{Mn}(p \leq 0.005)$ in the plant mortality were significant only in the 2nd crop cycle of Exp-west. 


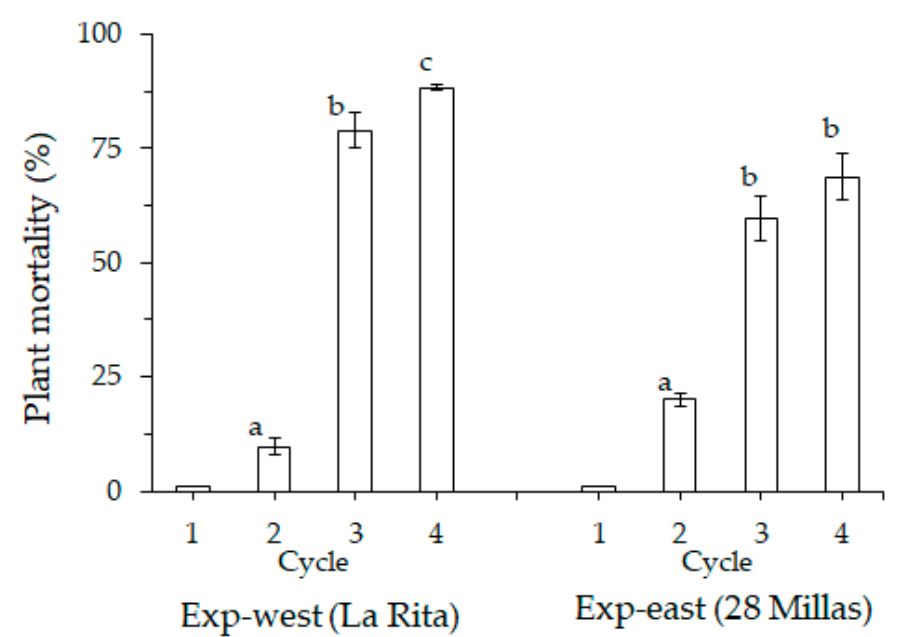

Figure 2. Aggregated plant mortality over all treatments by Fusarium wilt (Foc race 1) of Gros Michel banana during four crop cycles in two experiments (Exp-west in La Rita and Exp-east in 28 Millas) in the Costa Rican banana region. Bars with different letter in cycles are significantly different. $N=486$ in Exp-west and 1646 in Exp-east. (Ierror bars represent the standard error).

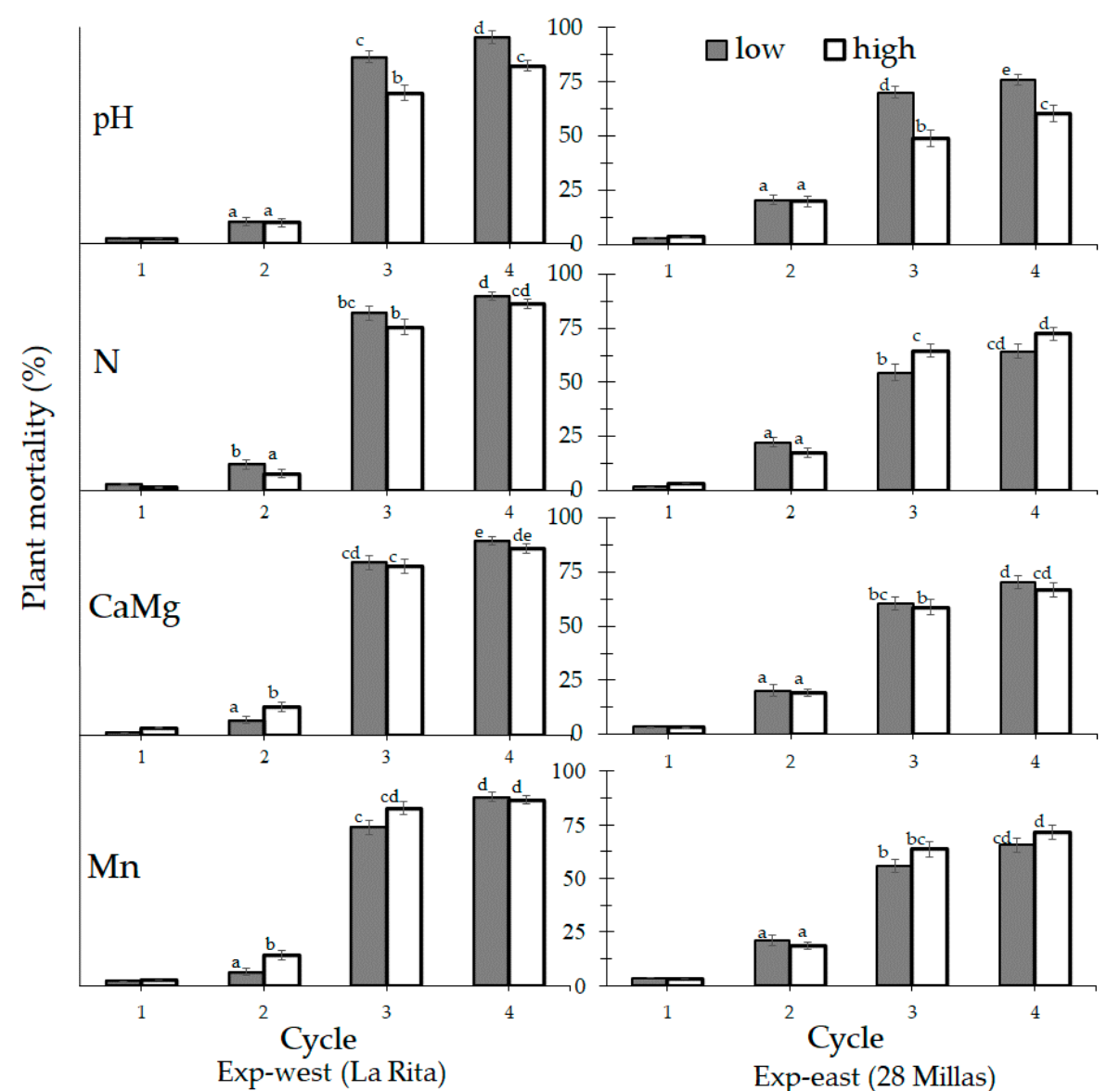

Figure 3. Plant mortality by Fusarium wilt (Foc race 1) of Gros Michel banana plants according to the management of four soil chemical properties $(\mathrm{pH}, \mathrm{N}, \mathrm{CaMg}$ and $\mathrm{Mn}$ ) during four crop cycles in two experiments (Exp-west in La Rita and Exp-east in 28 Millas) within the Costa Rican banana region. Bars with different letter in cycle are significantly different according to the soil property. Total plants per treatment is 243 in Exp-west and 823 in Exp-east. (error bars represent the standard error). 
The relation between plant mortality and soil $\mathrm{pH}$ for each individual plot in the 3rd crop cycle for both experiments is presented in Figure 4. The inconsistent results in the literature are not surprising, if we see the scatter in the relation between $\mathrm{pH}$ and mortality in the figure. However, the figure clearly shows that a low soil $\mathrm{pH}$ always corresponds to a high plant mortality irrespective of the other conditions. The clear role of soil $\mathrm{pH}$ is visually confirmed on an aerial photo of the plantation between the 2nd and the 3rd crop cycle in Exp-east (Figure 5). The aerial perspective shows a clear reduction in soil cover in the $\mathrm{pH}$-low plots as it was observed in both experiments.

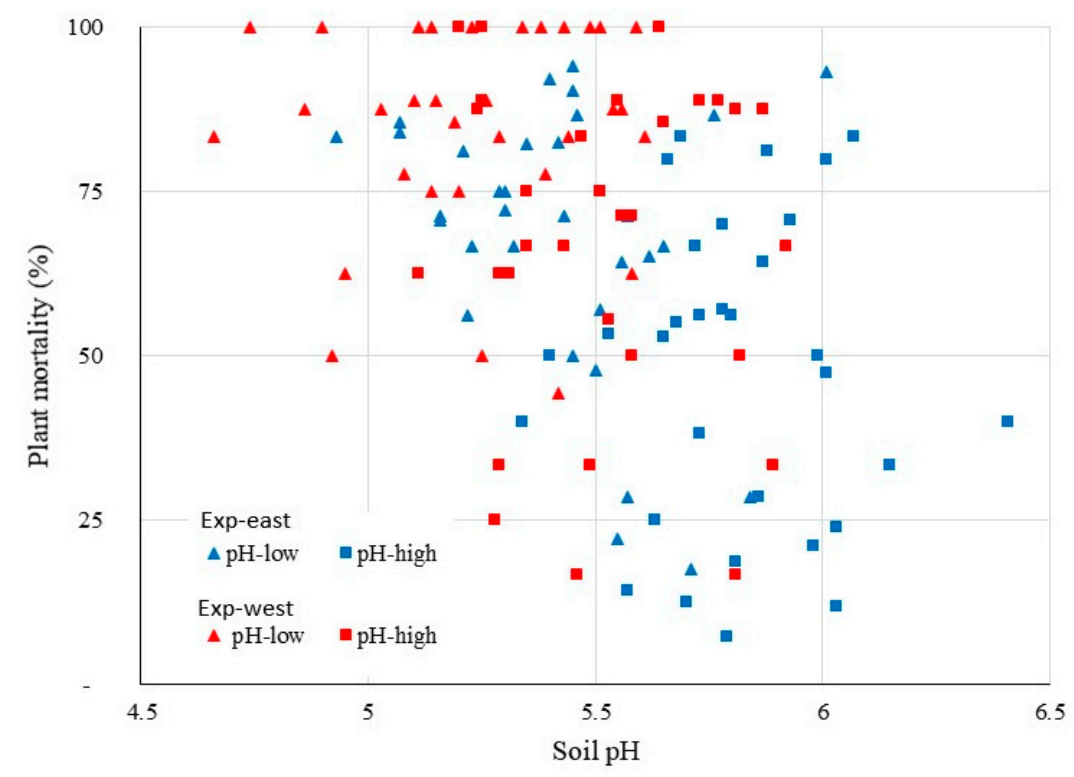

Figure 4. Plant mortality by Fusarium wilt (Foc Race 1) of Gros Michel banana as a function of soil $\mathrm{pH}$ during the 3rd and 4thcrop cycles of two experiments (Exp-west in La Rita and Exp-east in 28 Millas) within the Costa Rican banana region.

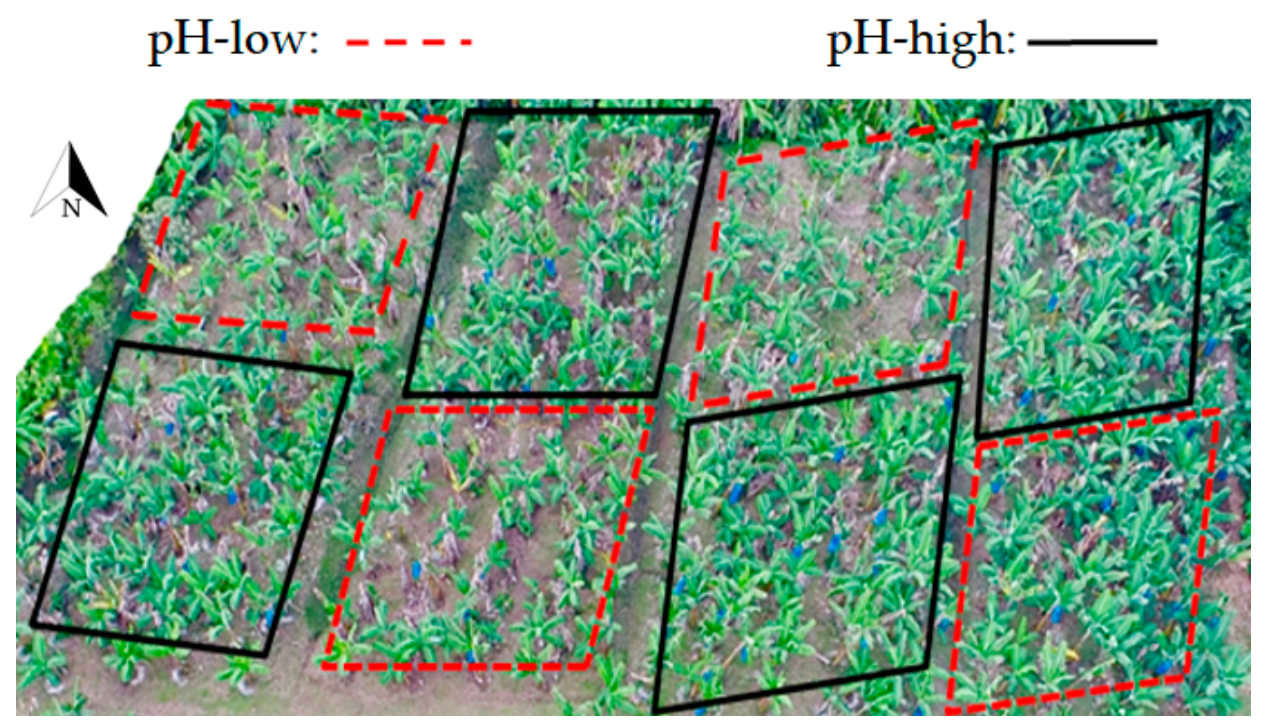

Figure 5. Aerial perspective from $30 \mathrm{~m}$ altitude of the impact of soil $\mathrm{pH}$ on plant mortality by Fusarium wilt (Foc race 1) of Gros Michel banana in the Exp-east in 28 Millas (Costa Rica) between the 2nd and 3rd crop cycles (aerial photo: Jean-François Michaud, CBC, Radio-Canada). 
In Exp-west, plant mortality was also influenced by the interaction of $\mathrm{pH}-$-low and $\mathrm{N}$ high $(p \leq 0.010)$, $\mathrm{pH}$-high and Mn-high $(p \leq 0.016)$, and CaMg-low and Mn-high $(p \leq 0.007)$ (Figure 6). There were no differences in plant mortality in relation of the interaction of the tested soil chemical properties in Exp-east (Figure 7).
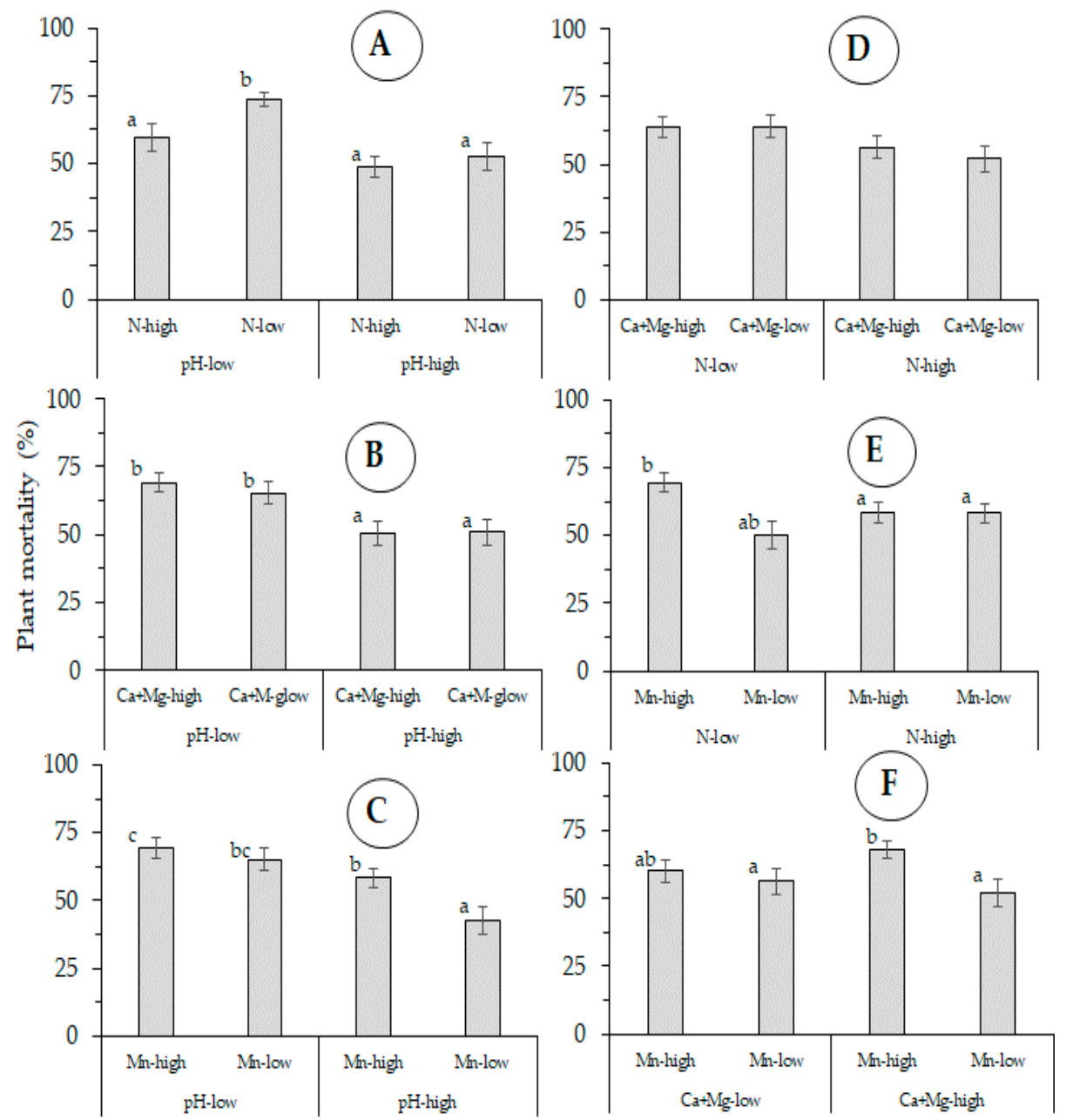

Figure 6. Aggregated effect of the interaction of five soil chemical properties: (A): $\mathrm{pH}-\mathrm{N},(\mathbf{B}): \mathrm{pH}-$ $\mathrm{CaMg}$, (C): $\mathrm{pH}-\mathrm{Mn},(\mathbf{D}): \mathrm{N}-\mathrm{CaMg}$, (E): N-Mn and (F): CaMg-Mn, on plant mortality by Fusarium wilt (Foc race 1) of Gros Michel banana after four crop cycles Exp-west (La Rita, Costa Rica). (error bars represent the standard error). 


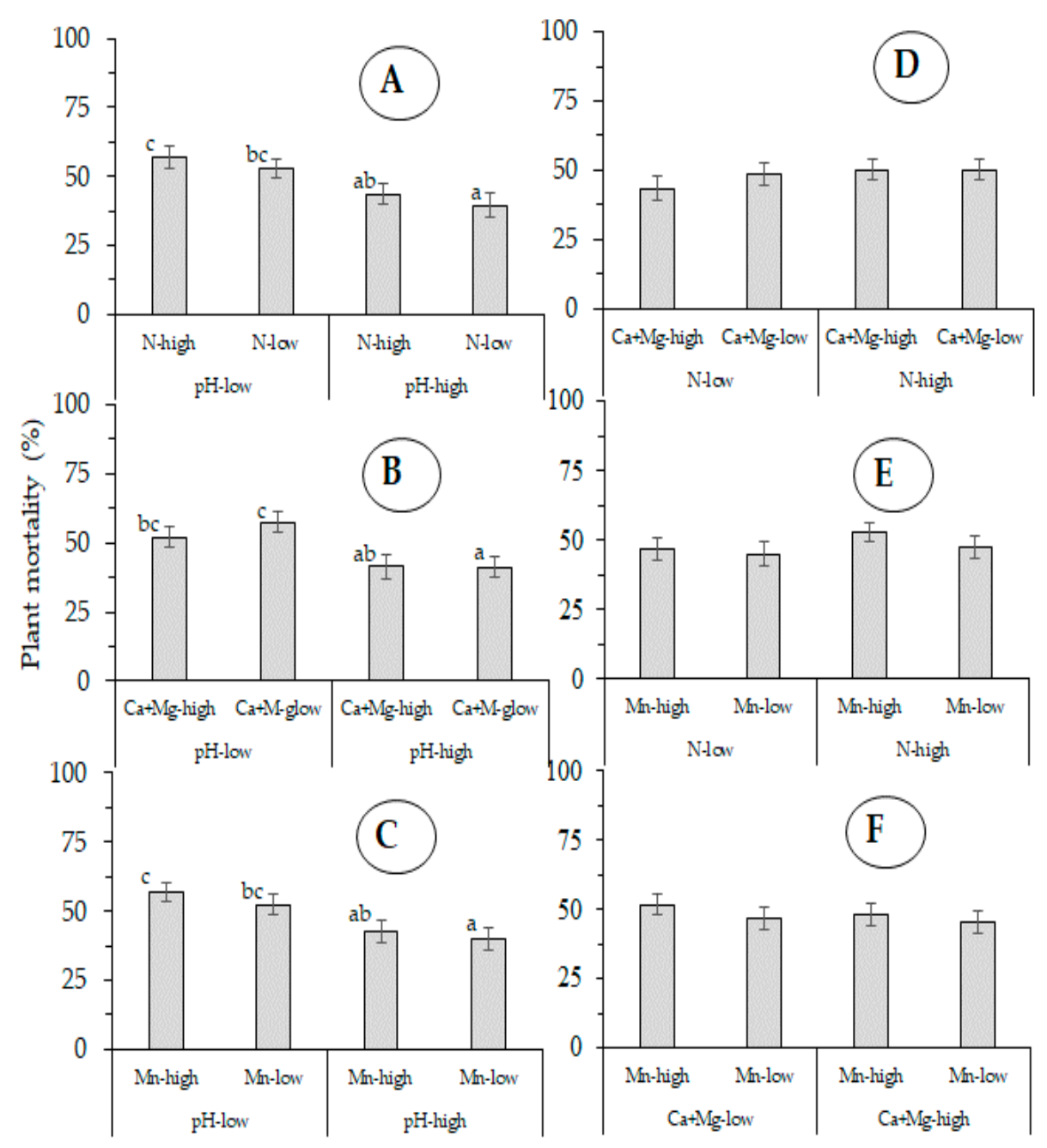

Figure 7. Aggregated effect of the interaction of five soil chemical properties: (A): $\mathrm{pH}-\mathrm{N},(\mathbf{B}): \mathrm{pH}-$ CaMg, (C): pH-Mn, (D): N-CaMg, (E): N-Mn and (F): CaMg-Mn, on plant mortality by Fusarium wilt (Foc Race 1) of Gros Michel banana after four crop cycles in Exp-east (28 Millas, Costa Rica). (error bars represent the standard error).

\subsection{Analysis for Managed Soil Chemical Properties}

Soil management resulted in significant differences in soil chemical properties in the second and the third analysis, during the four evaluated crop cycles in Exp-west. The trend in values for evaluated soil properties followed a significant trend with respect to the level for $\mathrm{pH}, \mathrm{Mg}$, and $\mathrm{Mn}$. In Exp-east, only $\mathrm{pH}$ and $\mathrm{Mn}$ maintained significant differences in the second analysis. In the third analysis, only soil $\mathrm{pH}$ presented a significant difference according to the soil treatment. The rest of the soil chemical properties did not present significant differences under the various treatments (Table 2). 
Table 2. Soil chemical properties in two experiments (Exp-west and Exp-east) from two locations (La Rita and 28 Millas respectively) of the Costa Rican banana region during the experimental period of four crop cycles. ( $n=32$ per soil chemical property in each region and crop cycle).

\begin{tabular}{|c|c|c|c|c|}
\hline \multirow[t]{2}{*}{ Treatment } & \multirow[t]{2}{*}{ Units } & \multicolumn{3}{|c|}{ Soil Analysis } \\
\hline & & Start & Cycle 1-2 & Cycle 3-4 \\
\hline \multicolumn{5}{|c|}{ Exp-west (La Rita) } \\
\hline N-low & $\%$ & n.d & 0.30 & 0.30 \\
\hline N-high & $\%$ & n.d & 0.31 & 0.30 \\
\hline pH-low & - & 5.5 & $5.4^{* * *}$ & $5.1^{* * *}$ \\
\hline pH-high & - & 5.5 & 5.7 & 5.6 \\
\hline Ca-low & $\operatorname{cmol}(+) \mathrm{kg}^{-1}$ & 4.60 & 4.18 & 4.06 \\
\hline Ca-high & $\operatorname{cmol}(+) \mathrm{kg}^{-1}$ & 4.60 & 4.26 & 4.26 \\
\hline Mg-low & $\operatorname{cmol}(+) \mathrm{kg}^{-1}$ & 2.90 & $1.41^{* *}$ & $1.84^{* * *}$ \\
\hline Mg-high & $\operatorname{cmol}(+) \mathrm{kg}^{-1}$ & 2.90 & 1.67 & 2.35 \\
\hline Mn-low & $\mathrm{mg} \mathrm{kg}^{-1}$ & 11 & $15 * * *$ & $16 * * *$ \\
\hline Mn-high & $\mathrm{mg} \mathrm{kg}^{-1}$ & 11 & 18 & 23 \\
\hline \multicolumn{5}{|c|}{ Exp-east (28 Millas) } \\
\hline N-low & $\%$ & n.d & 0.16 & 0.15 \\
\hline N-high & $\%$ & n.d & 0.17 & 0.14 \\
\hline pH-low & - & 6.3 & $5.4^{* *}$ & $5.4^{* * *}$ \\
\hline pH-high & - & 6.3 & 5.8 & 5.9 \\
\hline Ca-low & $\operatorname{cmol}(+) \mathrm{kg}^{-1}$ & 22.2 & 21.9 & 22.6 \\
\hline Ca-high & $\operatorname{cmol}(+) \mathrm{kg}^{-1}$ & 22.2 & 21.8 & 22.8 \\
\hline Mg-low & $\operatorname{cmol}(+) \mathrm{kg}^{-1}$ & 10.9 & 9.65 & 9.83 \\
\hline Mg-high & $\operatorname{cmol}(+) \mathrm{kg}^{-1}$ & 10.9 & 9.54 & 10.2 \\
\hline Mn-low & $\mathrm{mg} \mathrm{kg}^{-1}$ & 88 & $90 * * *$ & 88 \\
\hline Mn-high & $\mathrm{mg} \mathrm{kg}^{-1}$ & 88 & 133 & 87 \\
\hline
\end{tabular}

\subsection{Leaf Nutrient Concentration}

Leaf analyses only took place in the first two crop cycles. In the 3rd and 4th crop cycle plant mortality basically did not allow for proper sampling. The results of the leaf analyses are presented in Table 3. In the case of $\mathrm{N}$ and $\mathrm{Mn}$, the concentrations of the nutrients were significantly higher with the high levels in the treatment. The case of $\mathrm{N}$ is very specific as almost all nutrient concentrations are significantly higher in the N-high treatment compared to the $\mathrm{N}$-low treatment. The $\mathrm{K}$ concentrations were also found to be significantly different due to the $\mathrm{N}$-treatment, but the $\mathrm{K}$ contents were significantly lower in the N-high treatments. Although the treatments were designed to be rather extreme, only $\mathrm{N}$-treatment appeared to have an overall effect on nutrient uptake in both experiments.

Table 3. Leaf nutrient concentrations at the first and the second crop cycles of Gros Michel banana inoculated with Foc Race 1 in relation with two levels (high and low) of four soil chemical properties ( $\mathrm{pH}, \mathrm{N}, \mathrm{CaMg}$ and $\mathrm{Mn}$ ) in two experiments (Exp-west and Exp-east) from two locations (La Rita and 28 Millas respectively) in the Costa Rican banana region. ( $n=32$ per soil property per crop cycle and level of each soil chemical property).

\begin{tabular}{|c|c|c|c|c|c|c|c|c|c|c|c|}
\hline Treatment & $\mathbf{N}$ & $\mathbf{P}$ & $\mathbf{K}$ & $\mathrm{Ca}$ & $\mathrm{Mg}$ & $\mathbf{S}$ & $\mathrm{Fe}$ & $\mathrm{Cu}$ & $\mathrm{Zn}$ & Mn & B \\
\hline & \multicolumn{6}{|c|}{$\%$ dry matter ${ }^{-1}$} & \multicolumn{5}{|c|}{$\mathrm{mg} \mathrm{Kg}^{-1}$} \\
\hline & \multicolumn{11}{|c|}{ Exp-west (La Rita), 1st cycle } \\
\hline pH-low & 2.93 & 0.21 & 4.32 & 0.60 & 0.28 & 0.19 & 67 & 9 & 17 & $172 *$ & 8 * \\
\hline pH-high & 2.90 & 0.21 & 4.39 & 0.57 & 0.27 & 0.19 & 64 & 9 & 17 & 147 & 9 \\
\hline N-low & 2.86 & 0.21 & 4.43 & $0.56^{*}$ & 0.27 & $0.19 *$ & 67 & 9 & 17 & 149 * & 9 \\
\hline N-high & 2.96 & 0.21 & 4.28 & 0.61 & 0.29 & 0.20 & 64 & 9 & 16 & 169 & 8 \\
\hline CaMg-low & 2.92 & 0.21 & 4.34 & 0.58 & 0.27 * & 0.19 & 67 & 9 & 17 & 165 & 8 \\
\hline CaMg-high & 2.91 & 0.21 & 4.36 & 0.59 & 0.29 & 0.19 & 64 & 9 & 17 & 154 & 9 \\
\hline Mn-low & 2.89 & 0.21 & 4.40 & 0.57 & 0.28 & 0.19 & 65 & 9 & 17 & 149 * & 9 \\
\hline Mn-high & 2.94 & 0.21 & 4.30 & 0.60 & 0.28 & 0.20 & 66 & 9 & 17 & 170 & 8 \\
\hline
\end{tabular}


Table 3. Conts.

\begin{tabular}{|c|c|c|c|c|c|c|c|c|c|c|c|}
\hline Treatment & $\mathbf{N}$ & $\mathbf{P}$ & $\mathbf{K}$ & $\mathrm{Ca}$ & $\mathrm{Mg}$ & $S$ & $\mathrm{Fe}$ & $\mathrm{Cu}$ & $\mathrm{Zn}$ & Mn & B \\
\hline & \multicolumn{6}{|c|}{$\%$ dry matter ${ }^{-1}$} & \multicolumn{5}{|c|}{$\mathrm{mg} \mathrm{Kg}^{-1}$} \\
\hline & \multicolumn{11}{|c|}{ Exp-west (La Rita), 2nd cycle } \\
\hline pH-low & 2.55 & 0.19 & 3.77 & 0.67 & 0.28 & 0.18 & 58 & 7 & 17 & 183 * & $9 *$ \\
\hline pH-high & 2.54 & 0.19 & 3.82 & 0.75 & 0.26 & 0.18 & 57 & 7 & 17 & 163 & 11 \\
\hline N-low & $2.50 *$ & 0.20 * & $3.86 *$ & $0.66^{*}$ & 0.27 & 0.19 * & $59 *$ & 7 & 18 * & $155^{*}$ & 10 * \\
\hline N-high & 2.59 & 0.18 & 3.73 & 0.76 & 0.27 & 0.18 & 56 & 7 & 17 & 190 & 9 \\
\hline CaMg-low & 2.53 & 0.19 & 3.80 & 0.71 & 0.26 * & 0.18 & 58 & 7 & 17 & 176 & 10 \\
\hline CaMg-high & 2.56 & 0.19 & 3.79 & 0.71 & 0.28 & 0.18 & 57 & 7 & 17 & 170 & 10 \\
\hline Mn-low & 2.53 & 0.19 & 3.83 & 0.71 & 0.27 & 0.18 & 58 & 7 & 17 & 157 * & 10 \\
\hline \multirow[t]{2}{*}{ Mn-high } & 2.56 & 0.19 & 3.76 & 0.72 & 0.27 & 0.18 & 58 & 7 & 17 & 189 & 10 \\
\hline & \multicolumn{11}{|c|}{ Exp-east (28 Millas), 1st cycle } \\
\hline $\mathrm{pH}-\mathrm{low}$ & 2.42 & 0.19 & $3.70 *$ & 0.66 & 0.28 & 0.17 & 58 & 7 & 17 * & 408 & 12 \\
\hline pH-high & 2.44 & 0.19 & 3.58 & 0.63 & 0.27 & 0.17 & 56 & 7 & 16 & 351 & 12 \\
\hline N-low & $2.34 *$ & $0.20 *$ & $3.73 *$ & $0.60 *$ & $0.26 *$ & 0.17 & 57 & 7 & 17 & 355 & 12 \\
\hline N-high & 2.52 & 0.19 & 3.55 & 0.69 & 0.28 & 0.17 & 58 & 7 & 17 & 403 & 11 \\
\hline CaMg-low & 2.44 & 0.19 & $3.74 *$ & 0.65 & 0.27 & 0.17 & 58 & 7 & 17 & 378 & 12 \\
\hline CaMg-high & 2.43 & 0.19 & 3.54 & 0.64 & 0.28 & 0.17 & 57 & 7 & 17 & 382 & 12 \\
\hline Mn-low & 2.42 & 0.19 & $3.71 *$ & 0.64 & 0.27 & 0.17 & 57 & 7 & 17 & $366 *$ & 11 \\
\hline \multirow[t]{2}{*}{ Mn-high } & 2.45 & 0.19 & 3.57 & 0.65 & 0.28 & 0.17 & 58 & 7 & 17 & 394 & 12 \\
\hline & \multicolumn{11}{|c|}{ Exp-east (28 Millas), 2nd cycle } \\
\hline pH-low & 2.50 & 0.19 & 3.27 & $0.81 *$ & 0.36 & 0.18 & 66 & 8 & 17 & 298 & 10 \\
\hline pH-high & 2.49 & 0.19 & 3.27 & 0.89 & 0.36 & 0.18 & 67 & 7 & 17 & 272 & 11 \\
\hline N-low & $2.43^{*}$ & $0.20 *$ & $3.39 *$ & 0.78 * & 0.34 * & 0.18 & 67 & 7 & 17 & 289 & 11 \\
\hline N-high & 2.55 & 0.18 & 3.16 & 0.91 & 0.38 & 0.18 & 67 & 8 & 17 & 282 & 10 \\
\hline CaMg-low & 2.50 & 0.19 & 3.34 & 0.85 & 0.36 & 0.18 & 67 & 8 & 17 & 294 & 11 \\
\hline CaMg-high & 2.49 & 0.19 & 3.21 & 0.85 & 0.37 & 0.18 & 67 & 8 & 17 & 276 & 10 \\
\hline Mn-low & 2.51 & $0.20 *$ & 3.29 & 0.83 * & 0.36 & 0.18 & 67 & 8 & 17 & 287 & 11 \\
\hline Mn-high & 2.48 & 0.18 & 3.26 & 0.87 & 0.36 & 0.18 & 66 & 7 & 17 & 283 & 10 \\
\hline
\end{tabular}

${ }^{*} p<0.050$; comparison between the low and the high level of each soil treatment.

\subsection{Agronomic Performance}

Managing soil chemical properties had minimal influence on agronomic performance in the 1st and the 2 nd crop cycle. Only $\mathrm{N}$ influenced a direct effect on the bunch weight $(18.8 \mathrm{Kg}$ in N-low vs $19.9 \mathrm{~kg}$ in N-high) and clusters per bunch (8.9 in in N-low vs 9.0 in $\mathrm{N}$-high) in the 1st crop cycle of the Exp-east and CaMg in the bunch weight (26.2 kg in CaMg-low vs $24.8 \mathrm{~kg}$ in CaMg-high) in the 1st crop cycle of Exp-west. No differences in the rest of the agronomic variables were found in the two evaluated crop cycles. There were significant $(p \leq 0.050)$ differences in the average of the agronomic variables between the cycles in both experiments. The 2 nd crop cycle showed higher values respect to the 1 st crop cycle, as is usual in new banana plantations (Table 4).

Table 4. Agronomic performance in the 1st and 2nd of Gros Michel banana inoculated with Foc Race 1 in two experiments (Exp-west and Exp-east) from two locations (La Rita and 28 Millas respectively) of the Costa Rican banana region. ( $n=64$ in both experiments).

\begin{tabular}{|c|c|c|c|c|}
\hline \multirow[t]{2}{*}{ Variable } & \multicolumn{2}{|c|}{ Exp-West La Rita } & \multicolumn{2}{|c|}{ Exp-East 28 Millas } \\
\hline & 1st Cycle & 2nd Cycle & 1st Cycle & 2nd Cycle \\
\hline Plant height $(\mathrm{cm})$ & 337 & 369 & 300 & 355 \\
\hline Pseudostem circumference $(\mathrm{cm})$ & 75 & 83 & 64 & 79 \\
\hline Bunch weight (kg) & 25.2 & 29 & 19.3 & 24.8 \\
\hline Clusters bunch $^{-1}$ & 9.2 & 10.3 & 8.5 & 8.9 \\
\hline Harvested fruit $\S\left(\right.$ ton $\left.\mathrm{ha}^{-1}\right)$ & 39.9 & 41.3 & 30.6 & 31.8 \\
\hline
\end{tabular}

\$: 1600 plant ha ${ }^{-1} \times(100 \%-\%$ mortality $) \times$ average bunch weight in each cycle. 


\section{Discussion}

\subsection{Plant Mortality}

Plant mortality in relation to soil management was analyzed during four crop cycles. Despite the significative results with soil $\mathrm{pH}$ and its interactions with the other tested soil properties (the nutrients in this case), the very high plant mortality after the 2 nd crop cycle (exceeding the 60\%) prevented to verify the effect of those nutrients on FW expression. The plant mortality observed in both experiments after the 4th crop cycle exceeded that reported in the literature [17], possibly due to the artificial inoculation method used in our study. However, the time from the first inoculation to the end of the 2nd crop cycle was probably not long enough to present a higher level of infection.

Soil $\mathrm{pH}$ is described in the literature as an important indicator for soil health and banana production $[44,55]$. Our results clearly confirm that it also plays an important role in the expression of FW in banana as it was also reported in greenhouses studies [41]. In the 3rd and the 4th crop cycle, where the soil treatments showed significant effects in plant mortality, $\mathrm{pH}$ maintained a consistent behavior in its influence on the disease. Relatively low mortality rates were always linked to a higher soil $\mathrm{pH}$. It appears that increasing soil $\mathrm{pH}$ and avoiding soil acidification can reduce the impact of the disease in the medium-term.

A higher soil $\mathrm{pH}$ (near and up to 6.0) can be linked with improved plant development but also to the lower plant mortality caused by FW. Both direct and indirect effects of soil $\mathrm{pH}$ can be playing a role in the findings. As a main soil property, $\mathrm{pH}$ affects other biotic and abiotic soil properties [31,55-57]. The exact causal-effect of the suppressive effect of a higher soil $\mathrm{pH}$ values cannot be determined based on the current study. The variation in the effect could be caused by interactions with the other soil properties that were evaluated $(\mathrm{N}, \mathrm{CaMg}$, and $\mathrm{Mn}$ ).

The study demonstrated that soil management can modulate FW in banana. However, the high plant mortality rates also indicate how serious the disease is. The rapid development of the disease clearly hampers the cultivation of Gros Michel banana as a perennial crop in Foc infested soils. An alternative scenario would be annual cropping or for a maximum of two crop cycles. Otherwise, replanting every $4-5$ years can be considered for having an acceptable production under a high soil infestation with Foc. Implementing these alternatives requires a thorough cost/benefit analysis. Moreover, in a natural processes of plant inoculation (without the artificial forced inoculation in this experiment), a longer period to achieve the high disease mortality could be expected.

Nitrogen fertilization is an important cause for a lower soil $\mathrm{pH}$ in banana plantations. Particularly, the applied $\mathrm{N}$ ammonia sources in the experiments could decrease soil $\mathrm{pH}$. This $\mathrm{N}$ source is linked with a higher incidence of fungal diseases in crops [58]. Soil management has been identified as an option to suppress FW in banana [59]. The results show that it can slow down the impact of FW, but that soil management is still unable to control the disease.

The significant effect of $\mathrm{pH}$-low treatment can be associated to a higher Mn availability in these treatments. Soils in both experiments have high natural Mn concentrations. Natural $\mathrm{Mn}$ can be solubilized in $\mathrm{pH}-\mathrm{low}$, even in Mn-low treatments. Then the $\mathrm{pH}-\mathrm{Mn}$ interaction can be partially causing plant mortality in the $\mathrm{pH}$-low treatments. This interaction was more evident in the Exp-west with the lower soil fertility. The higher soil fertility in Expeast could hide the effect of the soil properties (except to $\mathrm{pH}$ and $\mathrm{N}$ ) and their interactions on the plant mortality. Moreover, the existence of the interactions of the soil properties in the expression of FW can imply a more complex scenario to use soil management to control or alleviate $\mathrm{FW}$ in banana.

The field experimentation brought along a high complexity to control the conditions in each experiment. The evaluated effect of soil management on FW expression was an indirect effect of the studied treatment. The disease expression in the plants was measured, but no data on the pathogen inoculum density in the soil were collected. Moreover, FW expression was certainly ruled by the artificial inoculation with Foc Race 1 . Although the potential direct effect of soil properties on the Foc population in the soil was not measured, it would be hidden 
to a certain extent by the Foc inoculation. Future studies should include the measurement of the Foc population before the plant inoculation and monitor the concentrations during the experiment to disentangle the direct and indirect effects of the treatments.

Although inoculation took place twice before the rapid increase in plant mortality in the third cycle, it appears that the level of infestation was not critical to induce the disease in the 1st and 2nd crop cycle. Time appears to play an important role in the accumulative effect of the fungus in the soil and in the plant. This artificial inoculation obviously differs from natural plant infestation of the production system. However, the consistency of the difference in the plant mortality according to soil $\mathrm{pH}$, even in the 3rd and 4th crop cycle, shows the importance of this soil property in FW development. In addition, the pathogen aggressiveness and dissemination could be influenced by the interaction of Foc with other biotic factors, such as nematodes [60] and the banana weevil [61], that may be influenced by soil management practices.

Experiments with diseases in perennial crops over a short period in, e.g., greenhouses may hide certain effects. Nevertheless, testing diseases in greenhouse experiments can give useful information about the relation of the soil and the crop disease, but it is typically concluded that it requires further evaluation at the field level [22]. In the current study, every crop cycle provided a different pattern of disease expression in relation to soil properties. The duration of experiments reported in the literature could be another reason for the inconsistent results in experiments with soil management [4].

The selection of representative locations is also important as illustrated by the differences between the two experiments were evident. This implies that only taking one subregion only tells part of the story, but also that the differences in ecological conditions can explain the inconsistent results in experiments with soil management and FW in bananas.

\subsection{Soil Analysis for Tested Soil Properties}

Some soil properties did not show significant differences in crop performance and FW. For example, the Ca concentration did not differ significantly between Ca-low and Ca-high. In addition, $\mathrm{Ca}$ and $\mathrm{Mg}$ concentrations dropped during the experiments. Similarly, despite the differences in $\mathrm{N}$ applications, the soil concentration did not differ significantly between $\mathrm{N}$-high and N-low. This can be explained by the perhumid conditions in the region and the exceptionally high rainfall of $6900 \mathrm{~mm}$ during the 1st and 2nd crop cycle that may have led to considerable nutrient leaching [62]. This could have caused the general drop in soil $\mathrm{pH}$ and the lack of differences in soil conditions in both experiments in the 1st and 2nd crop cycle, as shown in the second soil analysis. Nevertheless, it is evident that soils from Exp-east maintained a higher soil fertility than soils in Exp-west during the whole experimental period, except for the $\mathrm{N}$ concentration. The binding of soil organic matter to the allophanes in the volcanic ash soils in Exp-west may explain this specific difference for N [46,47]. The influence of soil management was less apparent in the fertile soils in Exp-east as shown by the similarity in nutrients concentration in these soils despite the differences in treatments. The lower inherent soil fertility in Exp-west makes it more likely to exhibit differences as a result of soil management.

\subsection{Leaf Nutrient Concentration According to Soil Management}

The higher mortality in the 3rd and 4th cycle could be linked in one hand with a higher Foc density due the death plants and in the other hand by the nutritional status of the plants due as indicated by the differences in nutrient concentrations in leaf samples. This effect was cumulative, and it began in the 1st and 2nd crop cycle. Nutrient concentrations can be linked to the plant predisposition to Foc $[16,17,19,63,64]$. However, it is difficult to draw hard conclusions as the fungus will damage the vessels in the plant resulting in problems with nutrient transport. Although soil $\mathrm{pH}$ and $\mathrm{N}$ can influence plant mortality by FW, integrated nutrient management based on leaf analysis can be part of the strategy to reduce the predisposition of the crop to the disease. 


\subsection{Agronomic Performance According to Soil Management}

Soil management influenced agronomic performance as expected [36] in the 1st and 2nd cycle. It appears that it is possible to maintain an acceptable crop production with a low impact of the disease at least during those crop cycles. Potentially, more intensive changes to soil management can delay the rapid increase in mortality. However, the agronomic performance of the "surviving plants" shows that production could be maintained in the first crop cycles after the inoculation. Although the infection appears to be devasting, gaining time to find alternative strategies through implementing practices, such as early detection and eradication of infested plants, replanting annual cropping, and crop rotation, may help to reduce yield losses considerably.

\section{Conclusions}

This study confirmed the potential role of soil management on FW expression in banana. The results of the field experiment were comparable to earlier results in greenhouse experiments with a very clear effect of soil $\mathrm{pH}$. Effects were most significant until the 3rd crop cycle after which the aggregated effect became very serious with very high mortality rates. Soil $\mathrm{pH}$ appeared to be a key factor explaining differences in mortality rates. A higher soil $\mathrm{pH}$ can alleviate FW expression in the first two crop cycles after planting. However, the interactions between the various soil properties limit the development of specific soil management strategies for FW control. Moreover, differences in plant mortality appear to be relatively small and not warrant the investment of a large soil management program to control FW in bananas at the farm level. However, maintaining a higher soil $\mathrm{pH}$ and applying adequate $\mathrm{N}$ doses and $\mathrm{Ca}$ and $\mathrm{Mg}$ fertilizers can be included as part of the strategy, focusing on reducing plant mortality and maintaining the production in the short and probably the medium term. Otherwise, these practices can be integrated with other crop management techniques, such as the early detection and eradication of infested plants to reduce inoculum pressure, replanting, annual cropping, and crop rotation, to alleviate the impact of FW on the production. This kind of medium term field experimentation is essential for banana and other perennial crops as the effects may clearly differ over the crop cycles. This allows to evaluate the accumulated effect of the disease over time and to minimize the risk of imprecise conclusions induced by partial results obtained in short term studies.

Author Contributions: All authors took part in the conceptualization of the research; R.A.S.M., J.A.S.F., J.J.S. and F.A.B.R. designed the experiments; R.A.S.M. and J.A.S.F. performed the experiments in the field; R.A.S.M. and J.J. managed the datasets; J.J.S. and F.A.B.R. performed the statistical analysis; F.A.B.R., R.A.S.M., J.J.S. and J.A.S.F. interpreted the results; R.A.S.M. wrote the manuscript; J.J.S., J.A.S.F. and F.A.B.R. made critical revisions and recommendations. All authors have read and agreed to the published version of the manuscript.

Funding: The study is financially supported by CORBANA and the Interdisciplinary Research and Education Fund (INREF) of Wageningen University.

Data Availability Statement: Data set supporting this publication is available in https:/ / osf.io/ 2jyse.

Acknowledgments: Raphael Hürliman MSc. for performing the soil classification in both experiments, Oscar Arias Moreira and Oscar Arias Rosabal Agronomist Eng. from Agribiotecnología de Costa Rica for providing the tissue culture plants of Gros Michel banana, Juan Z. Samuels Agronomist Eng. for supporting the field work and Claudiana Carr MSc. from CORBANA's Research Center (Laboratory of Biological Control) for collaborating in plants inoculation with the materials and procedures.

Conflicts of Interest: The authors declare no conflict of interest.

\section{References}

1. Oerke, E.-C.; Dehne, H.-W. Safeguarding production—Losses in major crops and the role of crop protection. Crop Prot. 2004, 23, 275-285. [CrossRef]

2. Oerke, E.-C. Crop losses to pests. J. Agric. Sci. 2005, 144, 31. [CrossRef]

3. Savary, S.; Ficke, A.; Aubertot, J.-N.; Hollier, C. Crop losses due to diseases and their implications for global food production losses and food security. Food Secur. 2012, 4, 519-537. [CrossRef] 
4. Stover, R.H. Fusarial Wilt (Panama Disease) of Bananas and Other Musa Species; The Common wealth Mycological Institute: Kew Surrey, UK, 1962.

5. Ploetz, R.C. Fusarium wilt of banana. Phytopathology 2015, 105, 1512-1521. [CrossRef]

6. Ploetz, R.C. Fusarium wilt of banana is caused by several pathogens referred to as Fusarium oxysporum f. sp. Cubense. Phytopathology 2006, 96, 653-656. [CrossRef]

7. Jones, C.F.; Morrison, P.C. Evolution of the banana industry of Costa Rica. Econ. Geogr. 1952, 28, 1-19. [CrossRef]

8. Harper, J.L. Studies in the resistance of certain varieties of banana to panama disease. Plant Soil 1950, 2, 383-394. [CrossRef]

9. Ploetz, R.C. Vegetative compatibility in Fusarium Oxysporum f.sp.cubense: Classifying previosly noncharacterized strains. Acta Hortic. 1990, 699-706. [CrossRef]

10. Perez-Vicente, L. Fusarium wilt (Panama disease) of bananas: An updating review of the current knowledge on the disease and its causal agent. Fitosanidad 2004, 8, 27-38.

11. Escobedo, A. Cadena Productiva de Banano Criollo ('Gros Michel') de Costa Rica; CATIE: Turrialba, Costa Rica, 2010.

12. Soto, M. Situación y avances tecnologicos en la producción bananera mundial. Rev. Bras. Frutic. 2011, 33, 13-28. [CrossRef]

13. Aurore, G.; Parfait, B.; Fahrasmane, L. Bananas, raw materials for making processed food products. Trends Food Sci. Technol. 2009, 20, 78-91. [CrossRef]

14. Buddenhagen, I. Understanding strain diversity in Fusarium oxysporum f. Sp. Cubense and history of introduction of "Tropical race 4" to better manage banana production. Acta Hortic. 2009, 828, 193-204. [CrossRef]

15. Stover, R.H.; Thornton, N.C.; Dunlap, V.C. Flood-fallowing for eradications of Fusarium Oxysporum F. Cubense: I. Effect of flooding on fungus flora of clay loam soils in Ulua Valley, Honduras. Soil Sci. 1953, 76, 225-238. [CrossRef]

16. Stover, R.H. Studies on Fusarium wilt of bananas. I. field control. Can. J. Bot. 1961, 39, 197-206. [CrossRef]

17. Rishbeth, J. Fusarium wilt of bananas in Jamaica. II. Some aspects of host-parasite relationships. Ann. Bot. NS 1955, XXI, 215-245.

18. Borges, A.; Trujillo JDC, I.; Gutierrez, F.; Angulo, D. Estudio sonre el Mal de Panamá en las Islas Canarias. II.-Influencia de los mecanismos de resistencia de la plantera (Cavendish enana) al Mal de Panamá. Fruits 1983, 38, 755-758.

19. Domínguez, J.; Negrín, M.A.; Rodríguez, C.M. Soil potassium indices and clay-sized particles affecting banana-wilt expression caused by soil fungus in banana plantation development on transported volcanic soils. Commun. Soil Sci. Plant Anal. 2008, 39, 397-412. [CrossRef]

20. Orr, R.; Nelson, P.N. Impacts of soil abiotic attributes on Fusarium wilt, focusing on bananas. Appl. Soil Ecol. 2018, 132, 20-33. [CrossRef]

21. Segura, R.A.; Stoorvogel, J.J.; Bosman, M.; Sandoval, J.A. Fusarium wilt (Foc race 1) in relation to soil properties in smallholder's farms with 'Gros Michel' banana (Musa AAA) in Costa Rica. CORBANA 2019, 45, 67-82.

22. Segura, R.A.; Stoorvogel, J.J.; Samuels, J.Z.; Sandoval, J.A. Managing the interactions between soil abiotic factors to alleviate the effect of Fusarium wilt in bananas. Acta Hortic. 2018, 163-168. [CrossRef]

23. Doran, J.W.; Sarrantonio, M.; Liebig, M.A. Soil health and sustainability. In Advances in Agronomy; Sparks, D.L., Ed.; Academic Press: San Diego, CA, USA, 1996; Volume 56, pp. 1-54. ISBN 978-0-12-000756-1.

24. Ghorbani, R.; Wilcockson, S.; Koocheki, A.; Leifert, C. Soil management for sustainable crop disease control: A review. Environ. Chem. Lett. 2008, 6, 149-162. [CrossRef]

25. Huber, D.; Römheld, V.; Weinmann, M. Relationship between nutrition, plant diseases and pests. In Marschner's Mineral Nutrition of Higher Plants; Elsevier: Amsterdam, The Netherlands, 2012; pp. 283-298. ISBN 978-0-12-384905-2.

26. Dordas, C. Role of nutrients in controlling plant diseases in sustainable agriculture. A review. Agron. Sustain. Dev. 2008, $28,33-46$. [CrossRef]

27. Amtmann, A.; Troufflard, S.; Armengaud, P. The effect of potassium nutrition on pest and disease resistance in plants. Physiol. Plant. 2008, 133, 682-691. [CrossRef] [PubMed]

28. Oritsejafor, J.J. Influence of moisture and $\mathrm{pH}$ on growth and survival of Fusarium oxysporum f.sp. elaeidis in soil. Trans. Br. Mycol. Soc. 1986, 87, 511-517. [CrossRef]

29. Höper, H.; Alabouvette, C. Importance of Physical and chemical properties in the suppressiveness of soils to plant diseases. Eur. J. Soil Biol. 1996, 32, 41-58.

30. Harrison, U.J.; Shew, H.D. Effects of soil $\mathrm{pH}$ and nitrogen fertility on the population dynamics of Thielaviopsis basicola. Plant Soil 2001, 228, 147-155. [CrossRef]

31. Janvier, C.; Villeneuve, F.; Alabouvette, C.; Edel-Hermann, V.; Mateille, T.; Steinberg, C. Soil health through soil disease suppression: Which strategy from descriptors to indicators? Soil Biol. Biochem. 2007, 39, 1-23. [CrossRef]

32. Sugimoto, T.; Watanabe, K.; Yoshida, S.; Aino, M.; Matsuyama, M.; Maekawa, K.; Irie, K. The Effects of inorganic elements on the reduction of phytophthora stem rot disease of soybean, the growth rate and zoospore release of phytophthora sojae. J. Phytopathol. 2007, 155, 97-107. [CrossRef]

33. Serrano, M.S.; Fernández-Rebollo, P.; Vita, P.; Sánchez, M.E. Calcium mineral nutrition increases the tolerance of quercus ilex to phytophthora root disease affecting oak rangeland ecosystems in Spain. Agrofor. Syst. 2012, 87, 173-179. [CrossRef]

34. Huber, D.M.; Jones, J.B. The role of magnesium in plant disease. Plant Soil 2012, 368, 73-85. [CrossRef] 
35. Brennan, R.F. The role of manganese and nitrogen nutrition in the susceptibility of wheat plants to take-all in Western Australia. Fertil. Res. 1992, 31, 35-41. [CrossRef]

36. Stoorvogel, J.J.; Segura, R.A. Nutrition and soil management in banana cultivation. In Achieving Sustainable Cuntivations of Banana, Volume 1: Cultivation Techniques; Kema, G.H.J., Drenth, A., Eds.; Burleigh Dodds Science Publishing: Cambridge, UK, 2018; pp. 223-234. ISBN 978-1-78676-156-9.

37. Gibson, D.J.; Connolly, J.; Hartnett, D.C.; Weidenhamer, J.D. Designs for greenhouse studies of interactions between plants. J. Ecol. 1999, 87, 1-16. [CrossRef]

38. Tripp, R.; Woolley, J. The Planning Stage of on-Farm Research: Identifying Factors for Experimentation; CIMMYT: Mexico City, Mexico; CIAT: Cali, Colombia, 1989; ISBN 978-968-6127-02-7.

39. Dale, J.; Paul, J.-Y.; Dugdale, B.; Harding, R. Modifying bananas: From transgenics to organics? Sustainability 2017, 9, 333. [CrossRef]

40. Hwang, S.-C.; Ko, W.-H. Cavendish Banana cultivars resistant to fusarium wilt acquired through somaclonal variation in Taiwan. Plant Dis. 2004, 88, 580-588. [CrossRef]

41. Segura-Mena, R.A.; Stoorvogel, J.J.; García-Bastidas, F.; Salacinas-Niez, M.; Kema, G.H.J.; Sandoval, J.A. Evaluating the potential of soil management to reduce the effect of Fusarium oxysporum f. sp. cubense in banana (Musa AAA). Eur. J. Plant Pathol. 2021. [CrossRef]

42. García-Bastidas, F.A.; Quintero-Vargas, J.C.; Ayala-Vasquez, M.; Schermer, T.; Seidl, M.F.; Santos-Paiva, M.; Noguera, A.M.; Aguilera-Galvez, C.; Wittenberg, A.; Hofstede, R.; et al. First report of fusarium wilt tropical race 4 in cavendish bananas caused by Fusarium odoratissimum in Colombia. Plant Dis. 2020, 104, 994. [CrossRef]

43. Lambert, J. Alarm as devastating banana fungus reaches the Americas. Nature 2019. [CrossRef] [PubMed]

44. Segura, R.A.; Serrano, E.; Pocasangre, L.; Acuña, O.; Bertsch, F.; Stoorvogel, J.J.; Sandoval, J.A. Chemical and microbiological interactions between soils and roots in commercial banana plantations (Musa AAA, cv. Cavendish). Sci. Hortic. 2015, 197, 66-71. [CrossRef]

45. Lopez, A.; Solís, P. Contenidos e interacciones de los nutrimentos en tres zonas bananeras de Costa Rica. CORBANA 1991, 15, 15-25.

46. Arias, F.; Mata, R.; Alvarado, A.; Serrano, E.; Laguna, J. Chemical properties and classifica-tion of soils cultivated with banana in the Caribbean lowlands of Costa Rica. Agron. Costarric. 2010, 32, 177-195.

47. Arias, F.; Alvarado, A.; Mata, R.; Serrano, E.; Laguna, J. Clay mineralogy and soil fertility of banana plantation alluvial soils at Costa Rica's Caribbean lowlands. Agron. Costarric. 2010, 32, 223-236.

48. Klinkert, S. A Mechanistic Approach to Soil Variability at Different Scale Levels: A Case Study for the Atlantic Zone of Costa Rica; Wageningen UR: Wageningen, The Netherlands, 2014.

49. Mehlich, A. Mehlich 3 soil test extractant: A modification of Mehlich 2 extractant. Commun. Soil Sci. Plant Anal. 1984, 15, 1409-1416. [CrossRef]

50. R Development Core Team. A Language and Environment for Statistical Computing: Reference Index; R Foundation for Statistical Computing: Vienna, Austria, 2010; ISBN 978-3-900051-07-5.

51. Højsgaard, S.; Yan, J. The R Package geepack for Generalized Estimating Equations. J. Stat. Softw. 2006, 15. [CrossRef]

52. Yan, J. Geepack: Yet another package for generalized estimating equations. R-News 2002, 2/3, $12-14$.

53. Yan, J.; Fine, J. Estimating equations for association structures. Stat. Med. 2004, 23, 859-874. [CrossRef]

54. Russell, V.; Buerkner, P.; Herve, M.; Love, J.; Rielbl, H.; Singmann, H. emmeans: Estimated marginal means, aka least-squares means. 2021, 34, pp. 216-221. Available online: https://cran.r-project.org/web/packages/emmeans/emmeans.pdf (accessed on 15 February 2021).

55. Pattison, A.B.; Moody, P.W.; Badcock, K.A.; Smith, L.J.; Armour, J.A.; Rasiah, V.; Cobon, J.A.; Gulino, L.-M.; Mayer, R. Development of key soil health indicators for the Australian banana industry. Appl. Soil Ecol. 2008, 40, 155-164. [CrossRef]

56. Chaperon, S.; Sauvé, S. Toxicity Interaction of Metals ( $\mathrm{Ag}, \mathrm{Cu}, \mathrm{Hg}, \mathrm{Zn}$ ) to Urease and Dehydrogenase Activities in Soils. Soil Biol. Biochem. 2007, 39, 2329-2338. [CrossRef]

57. Almeida, N.O.; Teixeira, R.A.; Carneiro, F.A.; de Oliveira, C.M.; Ribeiro, V.A.; Lobo Júnior, M.; Rocha, M.R. da Occurrence and Correlations of Nematodes, Fusarium Oxysporum and Edaphic Factors on Banana Plantations. J. Phytopathol. 2018, 166, 265-272. [CrossRef]

58. Huber, D.M.; Watson, R. Nitrogen form and plant disease. Annu. Rev. Phytopathol. 1974, 12, 139-165. [CrossRef] [PubMed]

59. Geense, P.; Pattison, A.B.; Kukulies, T.L.; Scholberg, J.M.S.; Molina, A.B. Can changes in soil properties in organic banana production suppress Fusarium wilt? Nat. Resour. 2015, 06, 181-195. [CrossRef]

60. De Rocha, A.J.; dos Ferreira, M.S.; de Rocha, L.S.; Oliveira, S.A.S.; Amorim, E.P.; Mizubuti, E.S.G.; Haddad, F. Interaction between Fusarium oxysporum f. sp. cubense and Radopholus similis can lead to changes in the resistance of banana cultivars to Fusarium wilt. Eur. J. Plant Pathol. 2020, 158, 403-417. [CrossRef]

61. Guillén, C.; Tixier, P.; Tapia Fernández, A.; Conejo Barboza, A.M.; Sandoval Fernández, J.A.; Lapeyre de Bellaire, L. Can the banana weevil Cosmopolites sordidus be a vector of Fusarium oxysporum f.sp. cubense race 1? Unravelling the internal and external acquisition of effective inoculum. Pest Manag. Sci. 2021, ps.6339. [CrossRef] [PubMed] 
62. Sandoval, J.A.; Guzmán, J.A.; Gonzálex, M.; Segura, R.A. Impacto de Eventos Climáticos Extremos Sobre la Producción de Banano en Costa Rica. Santa Catarina, Brasil. 2015. Available online: http://banana-networks.org/musalac/files/2015/11/ Jorge-Sandoval-Rafael-Segura.pdf (accessed on 15 February 2021).

63. Batista, E.; de Brito, E.; Henrique, C.; Arlington, R.; Cavalcanti, I. Influência de Fatores Químicos Do Solo Sobre a Incidência Do Mal-Do-Panamá Na Bananeira Cv. Pacovan Na Paraíba. Rev. Biol. E Ciênc. Terra 2008, 8, 100-109.

64. Deltour, P.; França, S.C.; Liparini Pereira, O.; Cardoso, I.; De Neve, S.; Debode, J.; Höfte, M. Disease Suppressiveness to Fusarium Wilt of Banana in an Agroforestry System: Influence of Soil Characteristics and Plant Community. Agric. Ecosyst. Environ. 2017, 239, 173-181. [CrossRef] 